\title{
A KÖZÖS EURÓPAI VIZUÁLIS MŪVELTSÉG REFERENCIAKERET SZERKEZETE, TARTALMA ÉS JELENTŐSÉGE MÁS MŰVÉSZETPEDAGÓGIAI TERÜLETEK SZÁMÁRA'
}

\section{THE COMMON EUROPEAN FRAMEWORK OF REFERENCE FOR VISUALLITERACY: STRUCTURE, CONTENT AND ITS POTENTIALS FOR OTHER FIELDS OF AESTHETIC EDUCATION}

\author{
ErnstWagner \\ PhD, egyetemi tanár, az Európai Vizuális Múveltség Hálózat alapító elnöke, München, Múvészeti Akadémia, \\ UNESCO Múvészeti és Kulturális Kutatóközpont, Erlangeni Egyetem, Németország \\ ernst@wagner-mchn.de
}

ÖSSZEFOGLALÁS

A képek alapvetően határozzák meg, hogyan fogadjuk be a környező világot. Tárgyak és képi megjelenítések befolyásolják, mit veszünk észre, és miben hiszünk. A vizuális kompetencia befolyásolja esztétikai élményeink minőségét is. A vizuális írástudás tehát nemcsak a személyiségfejlődésben fontos, hanem része a felelős és informált állampolgár műveltségének is. Ennek ellenére, nagy a különbség a vizuális írástudás széles körben elismert egyéni és társadalmi jelentősége és az iskolai oktatásban elfoglalt szerény helye között.

2010-ben kilenc ország hatvan kutatója, tantervfejlesztője részvételével azért alakult meg az Európai Vizuális Múveltség Hálózat (European Network for Visual Literacy, ENViL), hogy javítson ezen a helyzeten. A hálózat hároméves nemzetközi összehasonlító kutatás során európai és azon kívüli tanterveket, pedagógiai programokat és értékelési rendszereket elemzett, áttekintette a már elkészült matematikai, olvasási és nyelvi keretrendszereket, és megfogalmazta a Közös Európai Vizuális Múveltség Keretrendszert (Common Framework of Reference for Visual Literacy, CEFR-VL).

A keretrendszer célja, hogy megalapozza a tanterv- és tananyagfejlesztést, valamint a pedagógiai értékelést a vizuális nevelésben. A szerzők a vizuális műveltség meghatározásánál kompetenciaalapú megközelítést alkalmaztak. A vizuális műveltség olyan tanult képességek csoportja, amelyek segítségével képeket és tárgyakat alkothatunk és fogadhatunk be, és reflektálhatunk is az alkotó és befogadó folyamatokra. Ez a cikk bemutatja a referenciakeret szerkezetét és fogalmi klasztereit, és áttekinti a CEFR-VL validálása és finomítása érdekében zajló kutatásokat, melyek tovább folytatják az első európai szintű kísérletet a vizuális nyelv pedagógiai célú meghatározására.

${ }^{1}$ Fordította Kárpáti Andrea. 


\section{ABSTRACT}

Visualizations strongly influence the way we perceive the world. Visual objects and presentations influence what we see and believe and how we perceive the world. Visual competence also influences the quality of our aesthetic experience. Therefore, to be visually literate is important for a fully developed person but also for a responsible and empowered citizen. However, there is a discrepancy between the importance of Visual Literacy and it's too often marginal position in education.

Therefore, in 2010 a European Network for Visual Literacy (ENViL) was founded with more than sixty researchers, curriculum developers and teacher trainers from nine European countries. The network undertook a three-year international comparative survey of curricula, teaching programs and assessment strategies in Europe and worldwide, and studied already existing literacies of mathematics, reading, science and language use, and conceptualized the "Common Framework of Reference for Visual Literacy" (CEFR-VL).

This framework aims to be a tool for the development of curricula, lesson plans and assignments as well as assessment instruments. The framework uses a competency-oriented approach and defines Visual Literacy as a group of acquired competencies for the production and reception of images and objects and for the reflection on these processes. This paper outlines the structure and main conceptual clusters of CEFR-VL, and summarises ongoing research to validate and further develop results of the first collaborative European effort to map the visual domain for educational purpose.

Kulcsszavak: vizuális műveltség, vizuális nevelés, kompetencia, referenciakeret, összehasonlító pedagógiai kutatás

Keywords: visual literacy, art education, competence, frame of reference, comparative educational reseach

\section{MIÉRT VAN SZÜKSÉG EGY KÖZÖS EURÓPAI VIZUÁLIS MÜVELTSÉG REFERENCIAKERETRE?}

Kultúránkat egyre inkább a képiség határozza meg, a képek alapvető szerepet játszanak társadalmi és személyes kommunikációnkban. A vizualizáció erősen hat arra, hogyan látjuk a világot. A formatervezés gyakran dönt gazdasági siker és kudarc fölött, és ezen keresztül arról is, hogyan fejlődik a gazdaság, és lesz-e állásunk. Néha elég néhány karikatúra, hogy meggyülöljenek, üldözzenek, és veszélybe kerüljön az életed. A képi megjelenítések befolyásolják, miben és hogyan hiszünk. Végül, de nem utolsósorban: ha nem lenne képzőmüvészet és design, az élet nélkülözné a szépséget és képzelőerőt. Ezért a vizuális írástudás nélkülözhetetlen ahhoz, hogy egy fiatalból érett személyiség és felelős állampolgár váljon.

A vizuális írástudás definíciói közül Jennifer M. Brill, Dohun Kim és Robert Maribe Branch (2007) meghatározását tartjuk a legteljesebbnek: „A vizuális írástudás olyan, tanult képességelemek csoportja, amely lehetővé teszi, hogy képi üzeneteket olvassunk és hozzunk létre. 
A vizuálisan müvelt személy képes

a) környezetétől megkülönböztetni és jelentéssel felruházni a látható dolgokat;

b) statikus és dinamikus látványokat és tárgyakat létrehozni egy meghatározott alkotói technikával és müfajban;

c) megérteni és értékelni mások képi közléseit;

d) elképzelni, gondolatban létrehozni látványokat és látható dolgokat." (Brill et al., 2001)

A vizuális írástudás kiemelkedő jelentőségével ellentétes a terület marginális helyzete az oktatásban. Ez a helyzet sokakat nemzetközi szinten összehangolt cselekvésre ösztönözött, és 2010-ben kilenc európai ország hatvan szakértője megalakította az Európai Vizuális Müveltség Hálózatot (European Network for Visual Literacy, ENViL)². A kutatóközösség alulról jövő kezdeményezésként, az iskolai gyakorlatra alapozva kezdett hozzá a Közös Európai Vizuális Mủveltség Referenciakeret (Common Framework of Reference for Visual Literacy, CEFR-VL) megalkotásához. A képességrendszer célja, hogy eszközül szolgáljon tantervek, óravázlatok, iskolai feladatok és értékelő eszközök fejlesztéséhez egyaránt (Wagner-Schönau, 2016).

A CEFR-VL alapelvei:

- Az ENViL-kutatócsoport kompetenciaorientált megközelítést alkalmaz. Weinert (2001) szerint a kompetenciák „olyan kognitív képességek és készségek, melyekkel az egyén rendelkezik, vagy amelyeket képes elsajátítani, hogy meghatározott problémákat oldjon meg. A kompetenciák körébe tartozik a feladat megoldásához szükséges motiváció, akarat és készség is, amelyek szükségesek a sikeres és felelős problémamegoldáshoz, változó környezetekben" (Weinert, 2001).

- Az ENViL kutatói hálózat szerint a vizuális mủveltség tanult kompetenciák csoportja, amelyek segítségével képeket, tárgyakat, környezeteket hozhatunk létre, illetve reflektálhatunk mások vizuális alkotásaira.

- A vizuális műveltség európai referenciakeretének kidolgozásakor tekintetbe vettük Európa különböző kulturális és tantárgyspecifikus hagyományait, változó kulturális kontextusait.

\section{HOGYAN KÉSZÜLT A REFERENCIAKERET?}

Hogy közös kiindulópontokat találjunk, az ENViL-csoport a nemzeti, regionális és helyi tantervek szerkezetét és tartalmát összehasonlító kutatásokat végzett az európai országokban. Az elemzések segítettek megérteni, milyen műveltségi

\footnotetext{
${ }^{2}$ A kutatócsoport honlapja: URL1.
} 
anyagot és összefüggéseket tartanak fontosnak a különböző országok szakértői. A tartalmi körök sajátos megnevezései és egyes résztémák befoglalása vagy elhagyása ellenére úgy tủnt, az alapfogalmak szintjén jelentős egyezés mutatkozik. Például szinte valamennyi tanterv két azonos dimenzió, az alkotás (képek létrehozása és használata) és a befogadás (a képekre adott válasz) mentén épül fel. Ez a két dimenzió számos képességelemet foglal magában, és néha egy harmadik, az előző kettővel kölcsönhatásban lévő dimenzióval, a reflexióval egészül ki. ${ }^{3}$ Erre a tantervelemzésre alapozva az ENViL-közösség átfogó és rendszerező jellegü kompetenciamodellt dolgozott ki, amely magában foglalja ezeket a dimenziókat, és alapul szolgálhat tanórai feladatok, tantervek, értékelésrendszerek stb. kidolgozásához.

\section{MUNKÁNK KÖZÉPPONTJÁBAN: A CEFR-VL-KOMPETENCIAMODELL}

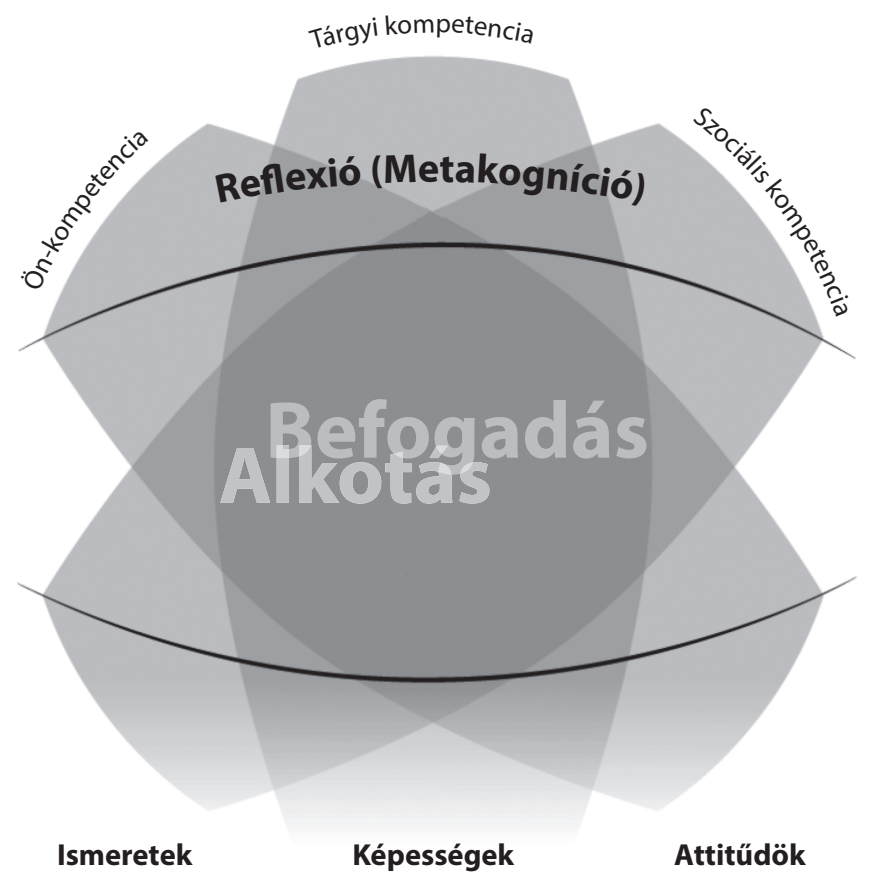

1. ábra. Az Európai Vizuális Műveltség Referenciakeret kompetenciastruktúra modellje.

Vizuális müveltség: képek és tárgyak reflektált alkotása és befogadása

(A magyar nyelvủ ábra forrása: Kárpáti-Pataky, 2016, 11.)

\footnotetext{
${ }^{3}$ A 'kép' szó a cikk eredeti szövegében ebben a mondatban a tág értelmű 'image' megjelöléssel szerepel, amely a látható világ ember alkotta jelenségeit: álló és mozgóképeket, tárgyakat, tereket is magában foglal (a fordító).
} 
A vizuális írástudás tanult képességeinek csoportját az egyes összetevőkben megjelenő tudás, részképességek és attitüdök meghatározásával írhatjuk le. Az 1. ábrán szereplő modell középpontjában a három fő dimenzió látható: alkotás, befogadás és reflexió (metakogníció). Bármit tanul is a diák (az alkotói vagy a befogadói szférában), mindenképpen szüksége van a metakognícióra ahhoz, hogy megérthesse, és így kontrollálhassa is saját tanulási folyamatát. A vizuális müveltség mint területspecifikus kompetencia az általános műveltségbe ágyazott, és kapcsolódik a személyes, illetve társas kompetenciákhoz, mint például az énkifejezés és kommunikáció, és a módszerek használatát irányító metodológiai kompetenciához is. A 2. ábrán látható, hogy az alkotás és befogadás képességcsoportja hogyan tagolható tovább. Fontos alkotóelemei a bemutatás, esztétikai élményszerzés, értékelés, felfogás, együttérzés, elemzés, használat, közlés, leírás, létrehozás, tervezés és vázlatkészítés is (a fogalmakat nem fontossági, hanem ábécésorrendben közöljük).

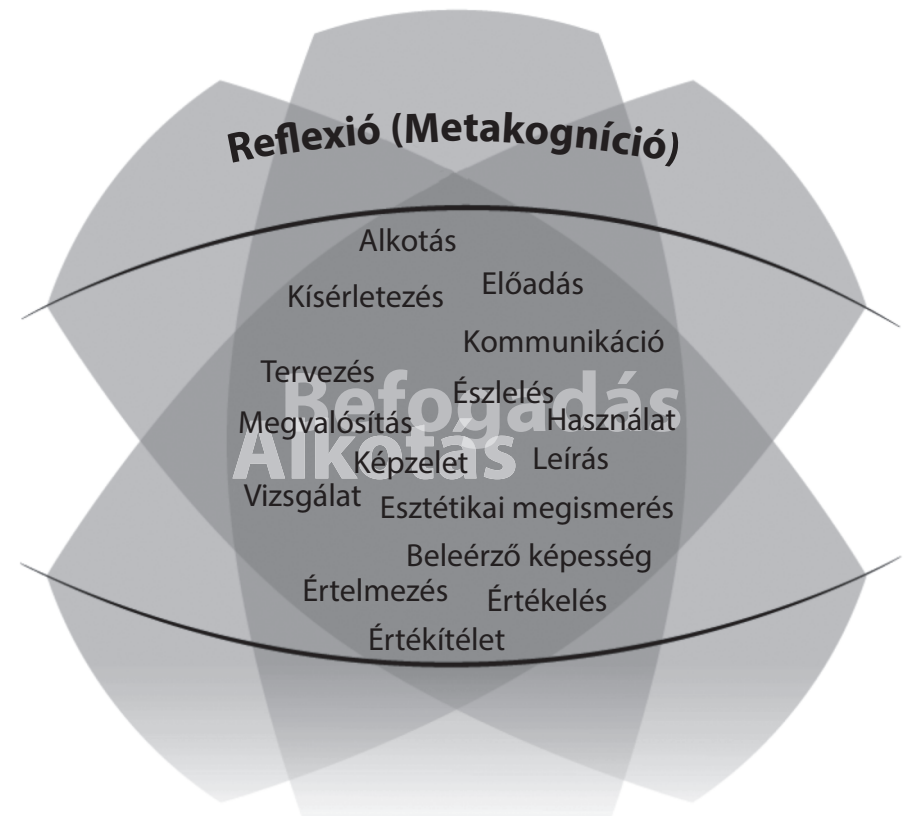

\section{Képek/tárgyak alkotása és befogadása, reflektált alkotás és befogadás}

2. ábra. A vizuális kompetencia alapvető összetevői az Európai Vizuális Mủveltség Referenciakeretben: a kompetenciaelemek elkülönítése 


\section{MIRE JÓ, ÉS HOGYAN HASZNÁLHATÓ A KOMPETENCIAMODELL?}

A vizuális müveltség olyan élethelyzetekben aktivizálódik, amikor egy vagy több vizuális képességelemünk használatára van szükség. ${ }^{4}$ A keretrendszer számos olyan releváns, már létező vagy előre látható, jövőbeli helyzetet ír le, amelyben vizuális müveltségre van szükség, és ezekre a kérdésekre ad választ:

- Milyen helyzetekben fogják használni a tanulók vizuális müveltségüket?

- Milyen cselekvésekre van szükségük ahhoz, hogy jól oldják meg ezeket a helyzeteket?

- Milyen emberek, helyek, cselekvési alkalmak és időszakok szerepelnek majd ezekben a helyzetekben?

- Milyen típusú képeket, tárgyakat használhatnak?

- Hogyan állítják elö képeiket és tárgyaikat, és milyen eszközöket, anyagokat használnak majd fel?

- Milyen tudásra (például más kultúrák, történelmi korszakok megismerésére) lesz szükségük ahhoz, hogy felelős módon formálhassák világukat?

A müveltségi (rész)területek megválasztása, amelyekre tanulóinkat fel kell készítenünk, messzemenő hatással van az oktatáspolitika döntéseire. Mi ezeket a területeket tartjuk fontosnak a vizuálisan müvelt európai polgárok oktatása és nevelése szempontjából:

- a személyes szféra (élet az otthonban, élet a barátokkal, szabadidőben, vásárlás, a lakókörnyezet berendezése, egy hobbi gyakorlása stb.);

- a közszféra, ahol az egyén a társadalom tagjaként cselekszik;

- a tanulás és a munka világa, ahol az egyén szervezett vagy informális tanulási és munkatapasztalatokat szerez.

A következő táblázat néhány példát tartalmaz a vizuális müveltség müködéséröl a személyes (privát) szférában.

1. táblázat. Példa egy helyzet leírására (privát szféra)

\begin{tabular}{|l|l|l|l|}
\hline \multicolumn{1}{|c|}{ Cselekvés } & $\begin{array}{l}\text { Képek, tárgyak, } \\
\text { müfajok, média }\end{array}$ & \multicolumn{1}{c|}{ Helyek } & \multicolumn{1}{c|}{ Alapkompetenciák, témák } \\
\hline $\begin{array}{l}\text { öltözéket } \\
\text { választani egy } \\
\text { bizonyos vizuális } \\
\text { hatás elérésére }\end{array}$ & $\begin{array}{l}\text { ruhadarabok, } \\
\text { ékszerek és egyéb } \\
\text { kiegészitök }\end{array}$ & $\begin{array}{l}\text { privát szféra (az } \\
\text { otthon), közszféra }\end{array}$ & $\begin{array}{l}\text { kulturális identitás, } \\
\text { interkulturális tudatosság, } \\
\text { kreativitás, életstílus, } \\
\text { önbizalom, aktív párbeszéd a } \\
\text { világgal, személyes kiteljesedés }\end{array}$ \\
\hline
\end{tabular}

${ }^{4}$ A CEFR-VL angol és német nyelven íródott, szövegében itt a gazdag jelentéstartalmú „,situation/die Situation” szó szerepel mint a vizuális müveltség megjelenésének kontextusa (a fordító). 
1. táblázat folytatása

\begin{tabular}{|c|c|c|c|}
\hline Cselekvés & $\begin{array}{l}\text { Képek, tárgyak, } \\
\text { müfajok, média }\end{array}$ & Helyek & Alapkompetenciák, témák \\
\hline $\begin{array}{l}\text { közvetlen } \\
\text { életterünk } \\
\text { (személyes } \\
\text { környezetünk) } \\
\text { megtervezése }\end{array}$ & $\begin{array}{l}\text { belsőépítészet, } \\
\text { képek, textilek, } \\
\text { bútor, növények, } \\
\text { világítás }\end{array}$ & $\begin{array}{l}\text { az otthon és a } \\
\text { kert }\end{array}$ & $\begin{array}{l}\text { életstílus, kreativitás, } \\
\text { kulturális identitás, } \\
\text { önbizalom, önkifejezés képi } \\
\text { eszközökkel, személyes } \\
\text { kiteljesedés }\end{array}$ \\
\hline $\begin{array}{l}\text { személyes } \\
\text { élmények } \\
\text { kifejezése képekkel } \\
\text { és tárgyakkal }\end{array}$ & $\begin{array}{l}\text { fotók, } \\
\text { emléktárgyak }\end{array}$ & $\begin{array}{l}\text { fényképalbum, } \\
\text { emlékek } \\
\text { gyüjtőhelye: } \\
\text { polc vagy } \\
\text { szekrényfiók } \\
\text { otthon, sírhely }\end{array}$ & $\begin{array}{l}\text { integráns személyiség, } \\
\text { cselekvőképesség, } \\
\text { önkifejezés képi eszközökkel, } \\
\text { életstílus, értékelés }\end{array}$ \\
\hline $\begin{array}{l}\text { vizuális média } \\
\text { használata a } \\
\text { szabadidőben }\end{array}$ & $\begin{array}{l}\text { képlejátszó } \\
\text { környezet, } \\
\text { digitális } \\
\text { interaktív média, } \\
\text { videofilm, } \\
\text { számítógépes } \\
\text { játék, zenés } \\
\text { videoklip }\end{array}$ & $\begin{array}{l}\text { virtuális tér, } \\
\text { valós környezet: } \\
\text { képernyő vagy } \\
\text { tévékészülék } \\
\text { otthon }\end{array}$ & $\begin{array}{l}\text { kulturális identitás, integráns } \\
\text { személyiség, kritikai } \\
\text { gondolkodás, nyitottság, } \\
\text { kíváncsiság, életstílus }\end{array}$ \\
\hline $\begin{array}{l}\text { más országbeli } \\
\text { szokások, rituálék } \\
\text { megfigyelése, } \\
\text { a bennük rejlő } \\
\text { esztétikai minőség } \\
\text { megértése }\end{array}$ & $\begin{array}{l}\text { multimodális } \\
\text { megjelenítés: } \\
\text { szokások, rítusok }\end{array}$ & $\begin{array}{l}\text { utazás, városi és } \\
\text { vidéki környezet }\end{array}$ & $\begin{array}{l}\text { interkulturális tudatosság, } \\
\text { kritikai gondolkodás, } \\
\text { nyitottság, kíváncsiság, } \\
\text { együttérzés, értékelés, } \\
\text { gondolatcsere, aktív dialógus } \\
\text { a világgal }\end{array}$ \\
\hline fogyasztás & $\begin{array}{l}\text { árucikkek, } \\
\text { hirdetések, } \\
\text { bemutatási } \\
\text { módok, } \\
\text { figyelemfelhívás, } \\
\text { csomagolás }\end{array}$ & $\begin{array}{l}\text { szupermarket, } \\
\text { üzletek, online } \\
\text { vásárlási } \\
\text { lehetőségek }\end{array}$ & $\begin{array}{l}\text { kritikai gondolkodás, } \\
\text { reflexivitás, képesség a } \\
\text { cselekvésre, életstílus }\end{array}$ \\
\hline
\end{tabular}

Ezt a helyzetgyüjteményt a tanárok órai feladatok tervezéséhez használhatják. Azok a feladatok, amelyeket a referenciakeretben szereplő, ilyen és hasonló leírások alapján készítenek el, megfelelnek a kompetenciaalapú oktatás követelményeinek, és a szokásos tanórai feladatoknál életszerübbek és relevánsabbak a tanulók számára. 


\section{KÉPESSÉGSZINTEK, SKÁLÁZÁS}

A CEFR-VL minden kompetenciaelemhez minőségi szinteket rendel, amelyekkel értékelhető a tanuló képességelemeinek fejlődése. A képességszintek bemutatják, hogyan képes a tanuló cselekedni egy adott helyzetben, adott feladat megoldása közben. A feladatoknak megfelelö kompetenciaelemekben elért szintek együttesen határozzák meg, mennyire sajátította el a tanuló a vizuális müveltségnek a feladattal számonkért részét. A keretrendszer általánosságban definiálja a képességszinteket, melyek nem kapcsolódnak egy-egy életkorhoz, oktatási helyzethez vagy tantervi típushoz. Céljuk az, hogy segítsék a feladatok megoldása során aktivizált készség- és képességelemeket azonosítani, és az egyes életkorokhoz és tantervi követelményekhez illesztett képességszint-definíciókat elkészíteni.

Annak érdekében, hogy érzékeltethetők legyenek a teljesítménybeli különbségek egyes területeken, „elemi”, „,középszintü” és „,kompetens” szinteket állapítanak meg. Az elemi szinten teljesítők már rendelkeznek az adott képességelem alapjaival, amelyekkel képesek személyiségüket fejleszteni, és részt venni a társadalom életében. A kompetens szint, ezzel szemben, a vizuális müveltség fejlettségének legmagasabb, átlagos képességü tanulók által elérhető fokát mutatja (ez a szint természetesen nem azonos a vizuális kultúrával hivatásszerüen foglalkozó müvész, tervező vagy múvészettörténész képességszintjével). Az értékelési rendszer illusztrálására alább az ,alkotás” képességdimenzióját mutatjuk be. Ennek tartalma elsősorban az elkészítés, létrehozás: vizuális formák (képek vagy tárgyak) szándékos megalkotása. A szintek a megoldás minőségét, a bemutatott kifejezöeszköz-készletet és a forma és tartalom közötti kapcsolatokat érzékeltetik.

2. táblázat. Egy példa a képességszintek meghatározására: az „alkotás” képességdimenziói

\begin{tabular}{|l|l|}
\hline \multicolumn{1}{|c|}{ Szint } & \multicolumn{1}{c|}{ Leírás } \\
\hline Elemi & $\begin{array}{l}\text { Képes kiválasztani a jól ismert motívumok és témák közül azokat, amelyek } \\
\text { illeszkednek alkotói szándékaihoz; képes az elöre meghatározott múvészi } \\
\text { formákat alkalmazni. } \\
\text { Képes szabályokat és elveket alkalmazni és kísérletezéseinek eredményeit a } \\
\text { témának megfelelő módon felhasználni. }\end{array}$ \\
\hline Középszintü & $\begin{array}{l}\text { Képes kiválasztani a megfelelö tartalmat, motívumokat és témát a javaslatok } \\
\text { alapján, figyelembe véve saját kifejezési szándékait. } \\
\text { Képes arra, hogy válasszon a rendelkezésére álló anyagok és eszközök közül, } \\
\text { figyelembe véve saját alkotói szándékait. } \\
\text { Képes figyelembe venni és saját kifejezési szándékának megfelelően néha } \\
\text { megszegni a múvészeti szabályokat, alapelveket. }\end{array}$ \\
\hline
\end{tabular}


2. táblázat folytatása

\begin{tabular}{|c|l|}
\hline \multicolumn{1}{|c|}{ Szint } & \multicolumn{1}{c|}{ Leírás } \\
\hline Kompetens & $\begin{array}{l}\text { A művészi kifejezőeszközök, tartalmak, motívumok széles körét képes } \\
\text { alkalmazni, és müvét, hogy elérje a tervezett hatást, a megfelelő formába } \\
\text { önteni. } \\
\text { Képes a vizuális alkotási módszereket és stratégiákat célirányosan és } \\
\text { összeszedetten, fókuszáltan alkalmazni, hogy jobban kifejezhesse saját vizuális } \\
\text { gondolatait. } \\
\text { Kritikusan reflektál a szabályokra és elvekre, és kifejezési szándéka érdekében } \\
\text { eldönti, hogy kövesse-e őket, vagy térjen-e el tölük. }\end{array}$ \\
\hline
\end{tabular}

\section{AZ ÉRTÉKELÉS MÓDJAI}

Minden tanár tudja, mennyire összetett folyamat egy fiatal tanulási útjának és eredményeinek minősítése. A kép- és tárgyalkotást vagy a vizuális befogadást gyakran tekintik elöre meghatározhatatlannak és alapvetően egyéni jellegünek. A tanárnak azonban képesnek kell lennie arra, hogy eldöntse, hogy a tanulási folyamat mely részében történik tudásátadás, képességfejlesztés, és ezeket hogyan értékelhetjük a tanulást monitorozó, formatív vagy egy oktatási szakaszt lezáró és az eredményességet feltáró, szummatív módszerekkel. Az értékelést nemcsak a tanár, hanem a tanuló is elvégezheti, egyedül vagy társaival. A tanulók által végzett (ön)értékelés előnye, hogy az értékelő eszköz egyben az oktatás eszközévé is válik, hiszen fejleszti az önszabályozó tanulás és a metakogníció képességeit.

A CEFR-VL részletes útmutatót és értékelési eszközöket nyújt a tanári, a társak által végzett és az önértékeléshez egyaránt. Az értékelö táblázat (assessment rubric) egy olyan pontozási segédlet, amely részletes szintleírásokat tartalmaz. A táblázatba foglalt értékelési kritériumok részletesen leírják a különböző képességszinteket, és így a követelmények a diákok számára is jól áttekinthetővé válnak. A táblázatot értékelésre és az egyes feladatokhoz kötődő, sajátos minősítő szempontok bemutatására is jól használhatjuk. A módszer hátránya a szöveges leírás, amelyet a diákok nem könnyen értelmeznek. Ezért kifejező ábrákkal érdemes segíteni a kritériumszintek megértését (Groenendijk et al., in print).

A 3. táblázatban két példa szerepel, amelyek az elemző képesség összetevőinek értékelését mutatják be. A vizuális (ön)értékelö lap (Visual Rubrics for/Self/ Assessment) részlete az alkotás dimenzió egyik részképességét, a kísérletezést jeleníti meg szimbolikus rajzzal, a másik a befogadás dimenzió egyik részképességét, az elemzést mutatja be ugyanígy. A képeken szereplő számok az egyes képességelemekben elért teljesítmény minősítésére szolgálnak. A tanár vagy a tanuló a teljesítménynek megfelelő szintet jelöli be az (ön)értékelő lapon. 


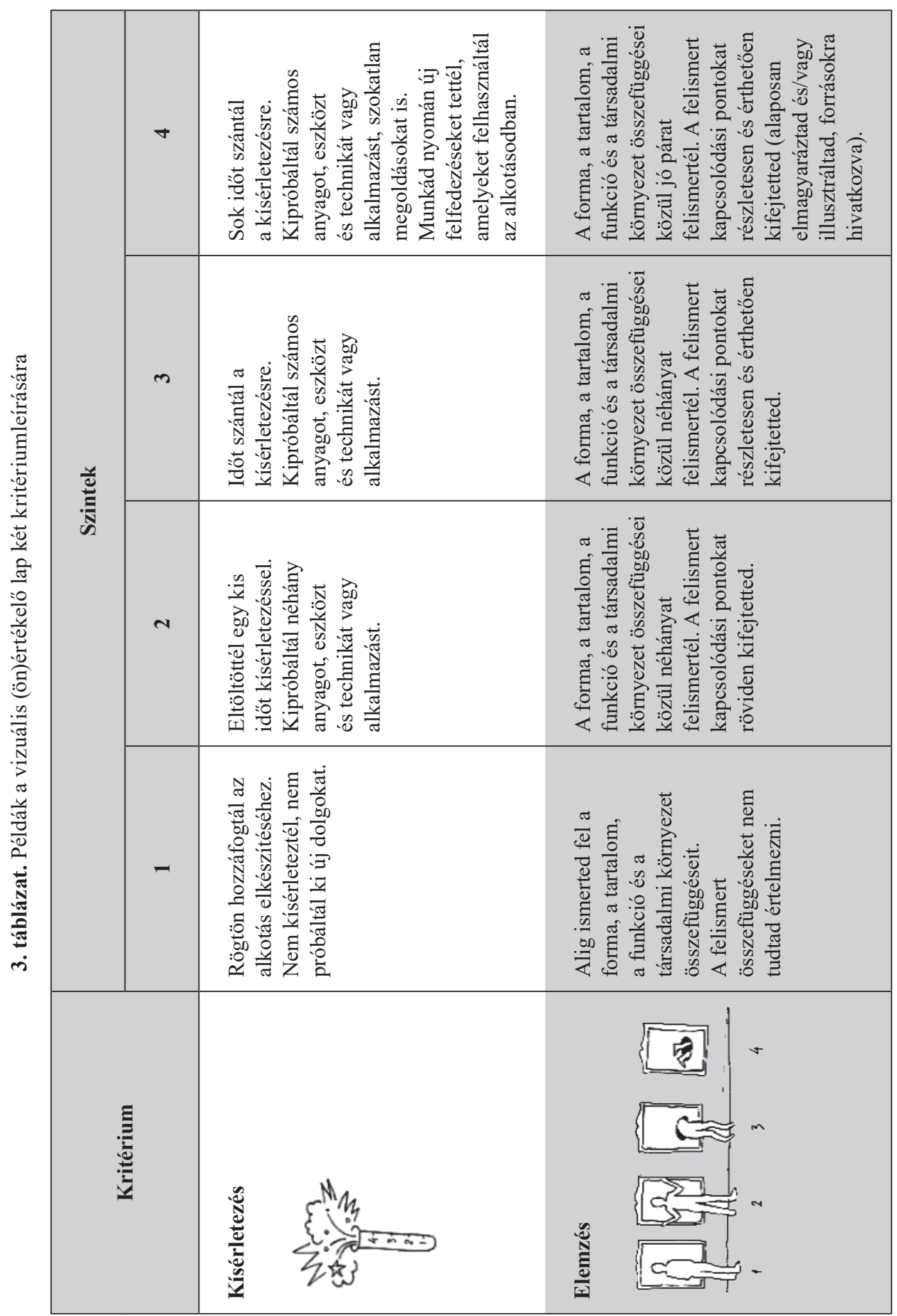




\section{ÖSSZEGZÉS}

A Közös Európai Vizuális Műveltség Referenciakeret (CEFR-VL) egy referenciadokumentum, amely a tantervírásban, tananyagok és taneszközök tervezésében és értékelési rendszerek kidolgozásában egyaránt hasznos segítőnk lehet. Másrészt, ez a referenciakeret alkalmas arra is, hogy megfigyeljük, leírjuk és elemezzük tanulóink vizuális képességeinek fejlődését. Segíti a tanár és a tanuló közötti dialógust, hiszen célja a tanácsadás, nem a standardok előírása.

Ha összevetjük ezt a keretrendszert az ének-zene, dráma- és színház-pedagógia és a tánc képességmodelljeivel, számos hasonlóságot fedezhetünk fel, amelyek segítenek a müvészetpedagógia fogalmi kereteinek tisztázásában. Ezért kutatócsoportunk a jövőben közös gondolkodást kezdeményez a társművészetek oktatóival, müvelőivel és kutatóival.

\section{IRODALOM}

Brill, J. M. - Kim, D. - Branch, R. M. (2007): Visual Literacy Defined: The Results of a Delphi Study - Can IVLA (Operationally) Define Visual Literacy? Journal of Visual Literacy, 27, 1, 47-60. http://www.aperture.org/wp-content/uploads/2013/05/vis-lit-data.pdf (letöltve 2016. 01. 06.)

Groenendijk, T. - Haanstra, F. - Kárpáti A. (in print): New Tool for Developmental Assessment Based on the Common European Framework of Reference for Visual Literacy - an international usability study. International Journal of Art and Design Education (IJADE)

Kárpáti A. - Pataky G. (2016): A Közös Európai Vizuális Mủveltség Referenciakeret. Neveléstudomány, 1, 6-21. http://nevelestudomany.elte.hu/index.php/2016/04/a-kozos-europai-vizualis-muveltseg-referenciakeret/ (Utoljára megnyitva: 2018. 04. 12.)

Wagner, E. - Schönau, D. (éd., ed., Hrsg.) (2016): Cadre Européen Commun de Référence pour la Visual Literacy - Prototype. Common European Framework of Reference for Visual Literacy - Prototype. Gemeinsamer Europäischer Referenzrahmen für Visual Literacy - Prototyp. Münster-New York: Waxmann

Weinert, F. E. (1999): Concepts of Competence. Theoretical and Conceptual Foundations. Manuscript. OECD, "Definition and Selection of Competencies (DeSeCo)". Neuchatel: DeSeCo, https://pdfs.semanticscholar.org/8b88/efa9dd5e0a4b605aea6e5e3b9ec640beb089.pdf

Weinert, F. E. (2001): Leistungsmessung in Schulen - Eine umstrittene Selbstverständlichkeit. In: Weinert, F. E. (Hrsg.): Leistungsmessung in Schulen. Weinheim: Beltz, 17-31. https:// homepage.univie.ac.at/henning.schluss/seminare/053-SE-Diplomandinnenseminar/Texte/weinert-2002-vergl-leistungsmessung.pdf

URL1: http://envil.eu 